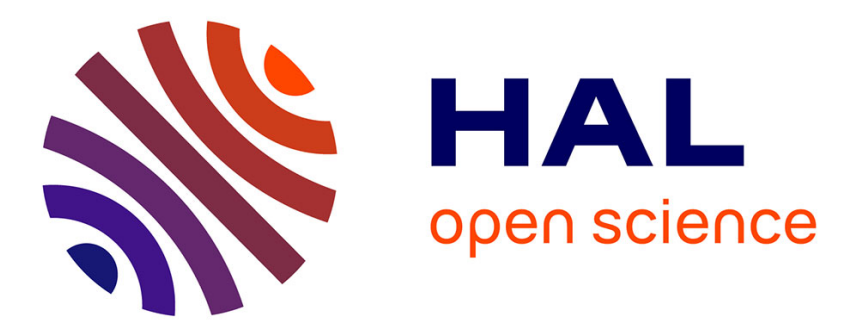

\title{
Assessment of conventional French railway sub-structure: a case study
}

Trong Vinh Duong, Yu-Jun Cui, Anh Minh A.M. Tang, Nicolas Calon, Alain Robinet

\section{- To cite this version:}

Trong Vinh Duong, Yu-Jun Cui, Anh Minh A.M. Tang, Nicolas Calon, Alain Robinet. Assessment of conventional French railway sub-structure: a case study. Bulletin of Engineering Geology and the Environment, 2015, 74 (1), pp.259-270. 10.1007/s10064-014-0575-y . hal-01271093

\section{HAL Id: hal-01271093 \\ https://hal-enpc.archives-ouvertes.fr/hal-01271093}

Submitted on 25 Apr 2018

HAL is a multi-disciplinary open access archive for the deposit and dissemination of scientific research documents, whether they are published or not. The documents may come from teaching and research institutions in France or abroad, or from public or private research centers.
L'archive ouverte pluridisciplinaire HAL, est destinée au dépôt et à la diffusion de documents scientifiques de niveau recherche, publiés ou non, émanant des établissements d'enseignement et de recherche français ou étrangers, des laboratoires publics ou privés. 
$4{ }^{1}$ : Ecole des Ponts ParisTech, U.R. Navier/CERMES, 6 - 8 av. Blaise Pascal, Cité Descartes,

5 Champs - sur - Marne, 77455 Marne - la - Vallée cedex 2, France

$6 \quad$ 2: French Railway Company (SNCF)

7

\section{Corresponding author:}

11 Prof. Yu-Jun CUI

12 Ecole des Ponts ParisTech

13 6-8 av. Blaise Pascal, Cité Descartes, Champs-sur-Marne

14 F-77455 Marne - la - Vallée cedex - France

15 Telephone: +33164153550

16 Fax: +33164153562

17 E-mail: yujun.cui@enpc.fr 


\section{Abstract}

20 A statistical study was firstly undertaken on problems occurred in a period of more than one year and

21 related to the circulation of train in the whole conventional French railway network. Emphasis was put 22 on the degradation of track components. The analysis evidenced the particular importance of sub-grade

23 quality in the performance of the whole track. After this general analysis, a conventional railway line in

24 the West of France was investigated. In the sub-structure of this line, an interlayer was identified that has

25 been created mainly by interpenetration of ballast and sub-grade. In the analysis, the degradation rate of

26 this line was correlated with different parameters such as the nature of sub-grades involved along the

27 line and the thickness of different layers. The results showed that the degradation rate is correlated to the

28 thickness of various layers. Furthermore, it was observed that the interlayer plays an important role in

29 the performance of tracks as it represents a transition layer before any train-induced stress is applied to

30 the sub-grade.

31 Keywords: Conventional French railway network; interlayer; sub-grade; degradation rate; NL; layer 32 thickness. 
36 Ballasted tracks are composed of two parts: super-structure (rail, fastening system and sleeper) and sub-

37 structure (ballast, sub-ballast and platform). To ensure the good performance of tracks and thus the

38 normal circulation of train, both super-structure and sub-structure need to be regularly examined and

39 maintained (Burrow et al. 2007). Normally, problems related to super-structure can be visually

40 determined and thus rapidly solved. It is however not the case for those related to sub-structure. Once

41 problems occur in the sub-structure, it is often difficult to explicitly identify and expensive to remediate.

42 Previous studies showed that the cost related to the maintenance of sub-structure often represents a huge

43 budget (Ebrahimi 2011; Indraratna et al. 2011). The experiences in France showed that after the track

44 remedial work to decrease rail deformations, the problems persist and the phenomenon as mud pumping

45 (fine particles of sub grade are pumped up to ballast surface), defects of bearing capacity occurs locally.

46 These observations suggest that problems are highly related to the behavior of sub-structure. From a

47 practical point of view, if the main mechanisms of the occurring problems are not understood, the origin

48 of the problems may remain even though expensive remedial works have been undertaken (Brough et al.

492003 ; 2006). The variability of sub-grade soils along a line often represents the major difficulty or

50 challenge for both the fundamental investigation and the practical operations.

51 An appropriate thickness of sub-structure layers is important for adequately distributing the train-

52 induced stress. If the track-bed layers do not have the required thickness, significant stress can be

53 transmitted to the sub-grade soils and important deformations can take place, leading to the degradation

54 of tracks. It is worth noting that the designed thickness of track-bed layers is not the same, depending on

55 the types of lines (for high speed train or normal train), on countries and also on the construction times

56 (Li and Selig 1998a; 1998b; Burrow et al. 2011). In France, the conventional railway lines were

57 constructed long time ago in 1850s, and the design in that time did not follow the current standards 
58 (Trinh 2011) in terms of super-structure composition, sub-structure mechanical behavior and

59 exploitation. This inevitably leads to stability-related problems for the tracks in case of increasing load,

60 traffic and speed of train. In particular, for the conventional railway tracks, as the ballast was mainly

61 installed directly onto the sub-grade during construction, a layer namely interlayer was created mainly

62 by the interpenetration of ballast and sub-grade soils (Calon et al. 2010; Trinh 2011; Trinh et al. 2011;

63 2012; Cui et al. 2013; Duong et al. 2013a; Duong et al. 2013b). The thickness and the hydro-mechanical

64 behavior of this interlayer can strongly affect the performance of the whole tracks.

65 This paper aims at assessing the performance of track sub-structure of the conventional French railway 66 network. Firstly, a statistical study on the French railway network was conducted. Problems related to

67 train circulation in the period from January 2010 to May 2011 were collected and analyzed. It was

68 concluded that it is important to conduct a global investigation followed by an in-depth sub-structure

69 one. In particular, the analysis showed that there is a good correlation between the train circulation

70 problems and the presence of fine particles in the sub-structure. After this global analysis, an in-depth

71 analysis was undertaken on one specific line with problems identified. The increase rate of the rail

72 geometrical degradation was studied. This increase rate was then correlated with other parameters such

73 as the natures of sub-grade involved along the line and the thicknesses of different layers.

\section{Assessment of the French railway network}

75 The problems related to train circulation (for instance, forced speed reduction in order to ensure the 76 comfort of passengers) were recorded in the French railway network from January 2010 to May 2011. A 77 total of 1705 cases was involved (Calon 2010). It was found that the causes can come from every track 78 components (steel rail, fastening system, sleeper, ballast, sub-ballast and sub-grade). Four main groups 79 can be defined as presented in Fig. 1, in relation to super-structure; sub-structure; speed reduction due to 80 maintenance/engineering works and "no information" meaning that the cause has not been explicitly 
81 found out, respectively. Among the 1705 cases, those related to the super-structure represent $16.13 \%$

82 (275 cases), to the sub-structure represent $17.89 \%$ (304 cases), to the maintenance and engineering

83 works represent $12.38 \%$ (211 cases), and $53.61 \%$ corresponds to "no information" (914 cases). The huge

84 number of "no information" cases is mainly due to the complexity of the track composition; it is often

85 difficult to determine the cause of a problem. On the other hand, this huge number confirms that railway

86 structures is a complex issue that needs extensive investigations in order to reveal the real mechanisms

87 involved in the problems. It is also worth noting that the part of problems related to the sub-structure

$88(17.89 \%)$ is a little higher than that related to the super-structure $(16.13 \%)$. This implies significant

89 maintenance works involving the sub-structure. Note that in the past, most attention has been paid to the

90 super-structure and the consideration given to the sub-structure is not enough to reveal all problems.

91 Among the sub-structure-related problems, there are 186 cases where clayey sub-grade was recorded and

92 very often mud pumping was observed. These zones are henceforth referred to as sensitive zones.

93 In order to enable the assessment of the French network in terms of economic indicators, the railway

94 lines are classified in different groups according to the nature and the importance of traffic (SNCF

95 1989). The classification, called UIC groups, is based on the fictive traffic $T_{f 2}$ calculated as follows:

$$
T_{f 2}=S \times T_{f 1}
$$

97 where $S$ is the coefficient of the line quality, and it is equal to 1 for the lines without passenger train or 98 local traffic, to 1.1 for the lines with passenger train at a speed lower than $120 \mathrm{~km} / \mathrm{h}$, to 1.2 for the lines 99 with passenger train at a speed from $120 \mathrm{~km} / \mathrm{h}$ to $140 \mathrm{~km} / \mathrm{h}$, to 1.25 for the line with passenger train at a 100 speed higher than $140 \mathrm{~km} / \mathrm{h} . T_{f 1}$ is the fictive weight calculated by:

$$
T_{f 1}=T_{v}+K_{m} T_{m}+K_{t} T_{t}
$$


where $T_{v}$ is the weight of passenger train (ton/day), $T_{m}$ is the weight of freight train (ton/day), $T_{t}$ is the

103 weight of locomotive (ton/day), $K_{m}$ is a coefficient (1.15 in normal case, 1.3 in the case of 20 ton axle

$104 \mathrm{load}), K_{t}$ is a constant which is equal to 1.4 .

105 According to the value of $T_{f 2}$, the corresponding UIC group can be defined. Table 1 presents all groups.

106 The order in this table follows the decreasing traffic and loading. In France, on the RFF (French

107 Department of Industry) network, there is no line within group 1. Based on the amplitude of fictive

108 traffic, the maintenance policy of SNCF (French Railway Company) was set up accordingly:

109 maintenance operations are undertaken more frequently for the first six groups and less for the other

110 groups.

111 As the total length of each group is not the same (Table 1), it appears necessary to normalize the number

112 of problems with respect to the length. The number of recorded problems per $1000 \mathrm{~km}$ of each UIC

113 group was then determined and the result is presented in Fig. 2. The first category corresponds to the

114 whole data recorded involving the problems related to all track components; the second category

115 corresponds to the sub-structure-related problems. The third category involves the sensitive zones. It is

116 observed that in the first category, the number of problems is indeed larger for the groups 2 to 4 . It is

117 group 4 that gathered the most part of problems.

118 When only the data related to sub-structure was taken into account, the configuration became different

119 and the greatest value was recorded for group 7 (passenger train). The same observation can be made

120 with the data related to the sensitive zones. This finding suggests that the maintenance policy should be

121 changed when referring to the sub-structure and more attention should be paid to the track bed within

122 group 7.

123 Problems occurred over a year are presented in Fig. 3a for the sub-structure and in Fig. 3b specifically

124 for the clayey sub-soils (sensitive zones). Very often, the mud pumping phenomenon occurs in the 

sensitive zones where the fine particles are pumped from sub-grade up to ballast surface and the whole

126 ballast layer becomes fouled and loses all its performance (Selig and Waters 1994; Indraratna et al.

127 2011). A similar configuration can be observed in two figures. There is a peak around the months of

128 February, March and April. In 2010, in the sensitive zones, the numbers of cases for these three months

129 are 28, 48 and 13, respectively; while those of other months are all lower than 10 . It is worth noting that

130 the period from February to April corresponds to late winter and early summer. It was reported in the

131 literature that ballast can be fouled after one winter due to freeze/thaw (Raymond 1999).

132 Fig. 4 presents the data recorded versus the type of tracks. Track 1 corresponds to the down line, Track 2 133 corresponds to the up line and "Other" corresponds to the single track line or secondary tracks. In the 134 case of sub-structure-related problems, the number for Track 1 (110 cases) is equal to that for Track 2 135 (109 cases), while in the case of sensitive zones-related problems, the number for Track 1 (71 cases) is 136 clearly larger than that for Track 2 (51 cases). Note that the drainage condition and the traffic for the 137 Track 1 and Track 2 are not always the same. As the quality of the drainage system is not always the 138 same, the water content can be different, hence different mechanical behaviors of soils can be expected 139 for the two tracks since water content is one of the key parameters governing the behavior of railway 140 sub-structure (Duong et al. 2013b).

141 Fig. 5 depicts the problems according to the territory. Note that the French railway network is divided 142 into three territories, each consisting of various infra-poles (sub-territory). It can be seen that Atlantique 143 is the territory where there is the largest number of problems. This observation is clearer if only the sub144 structure is accounted for (Fig. 5b). When considering the configuration in terms of sensitive zones (Fig. 145 5c), the contrast is even higher: the percentage of problems in Atlantique is 60\% against 22\% in South146 East and $18 \%$ in North East Normandy. Note that Atlantique is the territory with a long coast of Atlantic 147 Ocean and a large number of harbors with high frequency trading activities. However, Atlantique is also 148 the territory having the highest total line length, hence a possible higher problem number. 
149 Fig. 6 shows the distribution of problems in different infra-poles. It can be observed that the problems

150 occurred almost everywhere in France; however, most cases appeared in the infra-poles of "Ouest

151 Parisien" (West Paris) and Poitou Charentes. Based on this observation, one line situated in the infra-

152 pole of Poitou Charentes was selected for further in-depth investigation.

153 Assessment of a line in the infra-pole of Poitou Charentes

\section{Evaluated line}

155 A segment from kilometer 72 to 140 was selected. Information about the thicknesses of different layers

156 should be estimated based on the data from core samples and from Panda investigation (dynamic cone

157 penetrometer test) coupled with geo-endoscope observation.

158 This railway line was constructed in 1860s. It is classified in group 6 of UIC (see Table 1). As

159 mentioned before, like other conventional lines, this line was constructed with ballast directly overlying

160 the sub-grade. After years of circulations and operation, an interlayer was created as a result of the

161 interpenetration of ballast and fine particles of sub-grade soils (Trinh 2011; Cui et al. 2013; Duong et al.

162 2013b).

\section{Geological situation}

164 Fig. 7 presents the geological map of the studied line with the kilometer point (PK) and the geological 165 information. The sub-grade includes five soil types. The first one at the very first kilometer of the line

166 (from PK 74 to 75) consists of the soil of Middle Jurassic, mainly including hard limestone and marl.

167 The thickness of each layer can vary from $10 \mathrm{~mm}$ to $1 \mathrm{~m}$ and the total thickness can reach $20 \mathrm{~m}$. At PK

16875 , the line passes through a zone varying from river alluvial silty clay to clay-limestone. The second

169 (from 75 to 76) involves argillaceous limestone, marl, and to a lesser extent fine alluvial deposit and 170 peat. The thickness of these layers varies from some centimeters to $1 \mathrm{~m}$. The third consists mainly of 
marl (from 76 to 79 ). The total thickness reaches $40 \mathrm{~m}$. This marl layer can sometime be overlaid by a

172 thin layer of more or less clayey limestone. The fourth group (from 80 to 102) is the alternation of white

173 argillaceous limestone and marl. In several zones, the soil is very clayey with a very thin clay layer of

174 intercalation in marl or limestone. From PK 80 to PK 87, the limestone layers become very hard and

175 resistant. Around PK 87 and PK 89, the line passes through the zones of river alluvial silty clay and

176 sometimes with peat. These zones of peat are very compressible, representing low-quality sub-soils. The

177 fifth type involves marl, white chalky limestone and limestone sub-lithographic (Upper Jurassic). The

178 total thickness is about $30 \mathrm{~m}$. From PK 125 to PK 138, the soil consists of limestone with sandwiched

179 marl. This complex geological situation must be correlated to the large number of problems recorded.

180 The importance of geological situation for the track performance was also reported by Li and Selig

181 (1994), Revees et al. (2005), Bednarik et al. (2010).

\section{Longitudinal Leveling - NL}

183 For a smooth train circulation, rails/wheel contact must present a satisfactory leveling which is defined

184 referring to UIC group. In other words, leveling of rail is an indicator of track quality. Note that the

185 geometrical degradation of tracks that induces changes in leveling can be due to problems related to

186 super-structure, granular materials and platform (Guerin 1996). In the French railway network, the term

187 of longitudinal leveling NL (Nivellement Longitudinal in French) is used to assess the geometrical state

188 of tracks. A large value of $N L$ implies a bad state of railway line. Beyond a certain threshold of $N L$,

189 maintenance is required in order to bring $N L$ back to an admissible value (ballast tamping, stone blowing

190 and ballast renewal).

191 A train namely Mauzin train passes through a line for the measurement of rail deflection (Fig. 8a). NL is

192 calculated from the difference between the local leveling of each rail and the average profile of the line. 
193 The principle is to calculate the difference between the represent Euler and Lagrange of the wheel

194 ordinate (Rhayma 2010). From Fig. 8b, this difference $N$ is calculated as follows:

195

$$
\begin{aligned}
N & =z_{D}-\left(z_{D^{\prime}}-h\right) \\
& =z_{D}-\frac{1}{\alpha+\beta}\left(\beta z_{M}+\alpha z_{N}\right)+h \\
& =z_{D}-\frac{1}{4(\alpha+\beta)}\left[\beta\left(z_{A}+z_{B}+z_{C}+z_{D}\right)+\alpha\left(z_{E}+z_{F}+z_{G}+z_{H}\right)\right]
\end{aligned}
$$

196

$N L$ is the standard deviation of the recorded measurements with a mean value $\mu$ and for a distance of 200 197 m:

$$
N L=\sqrt{\frac{1}{M} \sum_{i=1}^{M}\left(N_{i}-\mu\right)^{2}}
$$

Fig. 9 presents the variations of $N L$ at kilometer 70.3 of Track 2 from 1997 to 2013. It can be observed

200 that the value of $N L$ decreased sharply after each maintenance (in the year of 2001, 2003, 2007 and

201 2012). However, after the maintenance, the value of $N L$ continued to increase at almost the same rate: a

202 linear increase trend of $N L$ over time can be identified. It is worth noting that the slope represents the

203 increase rate of $N L$ or the degradation rate of tracks. The increase trend of $N L$ persisted after a 204 maintenance, suggesting that ballast replacement did not resolve the problem, and the track degradation 205 was rather related to the sub-structure.

\section{Core sampler train}

207 The core sampler train is a special train which has the function as indicated by its name (SNCF 2011).

208 The train was equipped with drilling equipment. Sample tubes are driven dynamically into track-bed to

209 obtain a continuous core sample composed of ballast and underlying formations (Fig. 10). A digital

210 camera is used taking photographs of the sample. From the photograph (see Fig. 10), the thickness of 
211 each layer is analyzed and recorded. It can be seen that a typical track-bed consists of a clean ballast

212 layer underlying fouled ballast layer and/or interlayer and sub-grade soil. The sample tube allows core 213 sample to be taken till a depth of about $1.50 \mathrm{~m}$. This depth is enough for identifying the different layers

214 in the conventional railway track-beds. This investigation method was also reported in Brough et al.

$215(2003 ; 2006)$.

\section{Panda cone penetrometer and endoscope}

217 The first Panda penetrometer was presented in 1991 in France (Langton 1999) and it is nowadays widely 218 used thanks to its light weight and easy usage. Panda works following the principle of a dynamic cone 219 penetrometer that uses a manual hammer for driving a standard cone into the soil. The dynamic cone 220 resistance $\left(q_{d}\right)$ is then calculated and plotted versus the corresponding depth, giving the profile of $q_{d}$

221 (Langton 1999; Quezada 2012). The cone penetrometer is a useful tool for track-bed investigation and 222 for obtaining information about the in-situ characteristic of ballast and underlying sub-grade material.

Once the Panda test is performed, the rod is removed, leaving a small hole having the rod 224 dimension. This allows an endoscope, a very small digital camera, to be introduced into this hole to take 225 photographs of the materials involved. This provides a visual observation allowing the track-bed 226 components to be distinguished.

The Panda tests and endoscope observation were conducted along the studied line according to the SNCF standard (SNCF 2011). The obtained results allowed the thicknesses of different sub-structure

229 layers to be estimated. Fig. 11 presents typical results from Panda test and Endoscope observation at PK 230126.7 of Track 1. The correlation between the image of endoscope and the Panda results allowed the 231 identification of a layer of fresh ballast of $0.25 \mathrm{~m}$, a fouled ballast layer of $0.2 \mathrm{~m}$, an interlayer of $0.3 \mathrm{~m}$ 232 and the top of sub-grade at $0.95 \mathrm{~m}$ depth. As it is very difficult to distinguish fouled ballast layer and 233 interlayer, the sum of thickness of these two layers is accounted for in the following analysis. 
Fig. 12 depicts the degradation rate (the increase of $N L$ per year which was calculated from the

236 slope as presented in Fig. 9) versus the kilometer point for Track 1 and Track 2. On the whole, there is

237 an agreement between the data of two tracks; the peaks of Track 1 appeared almost at the same 238 kilometer points as the peaks of Track 2.

Fig. 13 and Fig. 14 present the degradation rates according to the year of rail (Fig. a) and the year

240 of sleeper (Fig. b) for Track 1 and Track 2, respectively. From these figures, it can be seen that there is

241 no correlation between the year of super-structure (rail or sleeper) and the increase rate of $N L$, even

242 though theoretically in the calculation of $N L$, the super-structure can have an influence on the value of

$243 N L$. It is worth noting that these data correspond to the year of the current super-structure, and that in

244 past the types of rail and sleeper could be different. Thus, it is not possible to exclude the contribution of

245 the super-structure to the degradation of tracks identified. However, as shown in Fig. 9, after the

246 remedial work of tamping, the value of $N L$ continued to increase. This suggests that the rail or sleeper

247 type did not clearly influence the evolution of $N L$ identified. Furthermore, admitting that the traffic, train

248 load and speed and the type of sleeper in two tracks are not necessary identical, the coincidence between

249 the degradation rates of Track 1 and Track 2 (Fig. 12) confirms that the general cause of the increase of

$250 \quad N L$ came from the sub-structure. Based on this observation, the following analysis focuses on the sub-

251 structure.

From Fig. 12, the zones with high degradation rates can be identified. They are around PK 73, 25379,88 , from 99 to 103 , from 106 to 114 and 122. Referring to the geological information, it can be

254 concluded that these kilometer points correspond to the zones where sub-grades contains large fraction 255 of fine particles. Around PK 73, the sub-grade is rather argillaceous limestone and marl. Around PK 79, 256 the sub-grade is fine alluvial deposits and peat. From PK 88 to 89, it is the alluvial deposits overlying the 
argillaceous limestone or marl or peat. From PK 98-103, the sub-grade involves argillaceous limestone,

258 marl and fine limestone. Around PK 113, the sub-grade contains sometimes colluviums. It is important

259 to note that these soils are sensitive to changes in water content and train loading. Soils like peat, alluvial

260 deposit and colluviums are very compressible and do not have the required mechanical properties for

261 sustaining the train-induced load. This can explain the high increase rate of $N L$ in these zones. From PK

262123 to the end of the line, the increase rate of $N L$ became low along the line, indicating a good

263 performance of the tracks. This can be also explained by the sub-grade nature: hard limestone is

264 involved along this section. For the first part of the line (up to PK 103), the sub-grade soils are quite

265 variable. These changes in soil natures are also detrimental to the track performance.

From the analysis above, it can be seen that the sub-grade has a significant influence on the

267 performance of railway structure. From a practical point of view, the zones with a sub-grade of low

268 mechanical properties are not apt to become the foundation of railway sub-structure. If it is inevitable,

269 improvement must be conducted in order to meet the requirements, such as a good drainage system or

270 some soil improvements.

Fig. 15 presents the correlation between the degradation rates of Track 1 and Track 2 . It is 272 observed that the $N L$ of Track 1 increased more quickly than that of Track 2 , because more data fall

273 below the equality line. This is in agreement with the finding in the first part of work where the number

274 of sub-structure related problems were recorded (Fig. 4). It is normally admitted that the train heading to

275 the center (up line) carrying more freights and passengers than the train leaving the center (down line).

276 More studies are needed to clarify this observation.

During the assessment of the whole line, the zones where fine particles were found on the ballast

278 layer surface were identified. The degradation rates of these zones are presented in Fig. 15 with the black

279 symbols. It can be seen that most of the zones with the presence of fine particles correspond to the zones 
with high increase rate of $N L$. These fine particles came probably from the sub-grade when mud

281 pumping occurred. This implies that the sub-grade containing large fraction of fine particles is 282 detrimental to the performance of sub-structure. Indeed, for this kind of sub-grade soils, a decrease of 283 mechanical performance can be expected when the moisture content rises. It appears thereby important 284 to further investigate the effect of water content of sub-soil having large fine particles fraction and also 285 the mud-pumping phenomenon.

Fig. 16 presents the correlation between the thickness of fouled ballast and interlayer $(e)$ and the 287 increase rate of $N L$ for special zones (Fig. a) and normal zones (Fig. b), for Track 1. The same 288 correlation is presented in Fig. 17 for Track 2. The special zones correspond to the zone of stations, the 289 zones with bridges or viaducts. The other zones are referred to normal zones. For the special zones, 290 Track 1 (Fig. 16a) presents a sharp decrease trend of degradation rate with the increase of $e$, while this 291 trend is not observed for Track 2 (Fig. 17a). For the normal zones, despite the data scatter that can be 292 explained by the presence of fouled ballast taken into account in the study, both Track 1 (Fig. 16a) and

293 Track 2 (Fig. 17a) present a decrease of degradation rate as the layers thickness increases. As mentioned

294 before, in the sub-structure of new lines for high speed train, there are a number of layers protecting

295 more or less the sub-grade. On the contrary, in the sub-structure of conventional lines with the absence 296 of an appropriate transition layer such as the sub-ballast layer, significant stress can be exerted to sub297 grade soils, leading to significant deformation of tracks or degradation of tracks. The presence of 298 interlayer somehow plays the role of a transition layer to reduce the stress applied to sub-grade. This 299 explains the decrease trend of the degradation rate with the increase of $e$.

This trend is also observed in Fig. 18 where the layer thickness deduced from Panda 301 penetrometer tests and endoscope observation is used. The trend is not clear for Track 1 but very clear 302 for Track 2. This confirms the positive impact of interlayer in reducing the degradation of tracks with the 303 increase of interlayer thickness. Note that in other countries, the presence of some layers such as capping 
304 layer or blanket layer that can protect sub-grade was also reported by Selig and Waters (1994);

305 Radampola et al. (2008); Burrow et al. (2011). In the study of Burrow et al. (2013) on the ole railway

306 embankment, it was found also that the settlement and the plastic strain decreased with the increase of

307 granular layer thickness.

\section{Conclusions}

This paper presents a statistical study on the problems related to the train circulation in the

310 French railway network, followed by an in-depth analysis of a conventional railway line in the West of

311 France. The conducted analyses and observations allow the following conclusions to be drawn:

312 - The maintenance of sub-structure is as important as that of super structure since the number of

313 problems identified in the whole French railway network for sub-structure was slightly larger than that

314 for super structure. In addition, because the problems related to sub-structure cannot be identified as

315 quickly as those related to super structure, it is recommended to pay more attention to sub-structure part.

316 - The sub-grade quality controls the degradation rate of tracks. The peak values of degradation

317 rate correspond to the zones where sub-grade is not mechanically stable, i.e., soils with large fraction of

318 fine particles. Moreover, frequent changes of sub-grade along a line are also detrimental to the 319 performance of tracks.

320 - Comparison between the two tracks of the studied line shows that Track 1 (up line) was

321 degraded faster than Track 2 (down line). More studies are needed to clarify this observation.

- There is a reasonable correlation between the degradation rate and the thickness of fouled

323 ballast layer and interlayer, suggesting a positive role of interlayer in reducing the degradation of tracks.

\section{Acknowledgements}


This study was carried out within the research project "Reuse and reinforcement of conventional

326 railway sub-structure and existing foundations". The authors would like to address their deep thanks to

327 Ecole des Ponts ParisTech (ENPC), French Railways Company (SNCF) and French Department of

328 Industry for their supports.

329 References:

330 Bednarik M, Magulová B, Matys M, Marschalko M (2010) Landslide susceptibility assessment of the 331 kralovany-liptovsky mikuláš railway case study. Physics and Chemistry of the Earth 35:162-171.

332 Brough M, Ghataora G, Stirling A, Madelin K, Rogers C, Chapman D (2003) Investigation of railway 333 track subgrade. Part 1: In-situ assessment. Proceedings of the Institution of Civil Engineers 334 Transport 156(3):145-154.

335 Brough M, Ghataora G, Stirling A, Madelin K, Rogers C, Chapman D (2006) Investigation of railway 336 track subgrade. Part 2: Case study. Proceedings of the Institution of Civil Engineers - Transport $337 \quad 159(2): 83-92$.

338 Burrow M, Bowness D, Ghataora G (2007) A comparison of railway track foundation design methods. 339 Proceedings of the Institution of Mechanical Engineers, Part F: Journal of Rail and Rapid Transit $340 \quad 221(1): 1-12$.

341 Burrow M, Ghataora G, Evdorides H (2011) Railway foundation design principles. Journal of Civil 342 Engineering and Architecture 5(3):224-232.

343 Burrow M, Ghataora G, Gunn D (2013) An investigation of the suitability of the construction of an old 344 railway embankment for a new freight route. International Journal of Geotechnical Engineering, $345 \quad 7(3): 292-303$. 
346 Calon N, (2010) Etude de recommandation en vue d'assurer de façon pérenne le RVL 220 sur Niort - La

347 Rochelle. Technical report, SNCF. (In French)

348 Calon N, Trinh VN, Tang AM, Cui YJ, Dupla JC, Canou J, Lambert L, Robinet A, Schoen O (2010)

349 Caractérisation hydromécanique des matériaux constitutifs de plateformes ferroviaires anciennes.

350 Conférence JNGG2010, Grenoble, France, pp. 787-794. (In French)

351 Cui YJ, Duong TV, Tang AM, Dupla JC, Calon N, Robinet A (2013) Investigation of the hydro-

352 mechanical behavior of fouled ballast. Journal of Zhejiang University- Science 144(4):244-255.

353 Duong TV, Trinh VN, Cui YJ, Tang AM, Nicolas C (2013)a Development of a large-scale infiltration

354 column for studying the hydraulic conductivity of unsaturated fouled ballast. Geotechnical Testing

$355 \quad$ Journal 36(1):54-63.

356 Duong TV, Tang AM, Cui YJ, Trinh VN, Dupla J, Calon N, Canou J, Robinet A (2013)b Effects of fines

357 and water contents on the mechanical behavior of interlayer soil in conventional railway sub-

$358 \quad$ structure. Soil and Foundations 53(6):868-878.

359 Ebrahimi A (2011) Behavior or fouled ballast. Railway Track and Structures 107(8):25-31.

360 Guerin N (1996) Approche expérimentale et numériques du comportement du ballast des voies ferrées.

$361 \quad$ PhD Dissertation, Ecole Nationale des Ponts et Chaussées. (In French)

362 Langton DD (1999) The panda lightweight penetrometer for soil investigation and monitoring material 363 compaction. Ground Engineering 1999, September.

364 Indraratna B, Salim W, Rujikiatkamjorn C (2011) Advanced Rail Geotechnology - Ballasted Track. 365 CRC Press. 
366 Li D, Selig ET (1994) Resilient modulus for fine-grained subgrade soils. Journal of geotechnical 367 engineering 120(6):939-957.

368 Li D, Selig ET (1998a) Method for railroad track foundation design. I: Development. Journal of 369 Geotechnical and Geoenvironmental Engineering 124(4):316-322.

370 Li D, Selig ET (1998b) Method for railroad track foundation design. II: Applications. Journal of 371 Geotechnical and Geoenvironmental Engineering 124(4):323-329.

372 Quezada JC (2012) Mécanismes de tassement du ballast et sa variabilité. PhD dissertation, Université $373 \quad$ Montpellier 2. (In French)

374 Radampola SS, Gurung N, McSweeney T, Dhanasekar M (2008) Evaluation of the properties of railway 375 capping layer soil. Computers and Geotechnics 35(5):719-728.

376 Raymond GP (1999) Railway rehabilitation geotextiles. Geotextiles and Geomembranes 17(4):213-230.

377 Reeves HJ, Kessler H, Freeborough K, Lelliott M, Gunn DA, Nelder LM (2005) Subgrade geology

378 beneath railways in Manchester. In: Railway Engineering 2005, London, UK, 2005.

379 Rhayma N (2010) Contribution à l'évolution des méthodologies de caractérisation et d'amélioration des $380 \quad$ voies ferrées. PhD Dissertation, Université Blaise Pascal - Clermont II. (In French)

381 Selig ET, Waters JM (1994). Track geotechnology and substructure management. Thomas Telford.

382 SNCF (1989) Armement, ballastage et entretien de la voie généralités classement des lignes en groupes 383 au point de vue de la maintenance de la voie- ef $2 \mathrm{a} 1 \mathrm{n}^{\circ} 1$. Technical report. (In French)

384 SNCF (2011) Référentiel Infrastructure - Procédure IN4103. (In French). 
385 Trinh VN (2011) Comportement hydromécanique des matériaux constitutifs de plateformes ferroviaires

386 anciennes. PhD Dissertation, Ecole Nationales des Ponts et Chaussées - Université Paris - Est. (In $387 \quad$ French)

388 Trinh VN, Tang AM, Cui YJ, Dupla JC, Canou J, Calon N, Lambert L, Robinet A, Schoen O (2012)

389 Mechanical characterization of the fouled ballast in conventional railway track substructure by large$390 \quad$ scale triaxial tests. Soils and Foundations 52(3):511-523.

391 Trinh VN, Tang AM, Cui YJ, Canou J, Dupla JC, Calon N, Lambert L, Robinet A, Schoen O (2011)

392 Caractérisation des matériaux constitutifs de plate-forme ferroviaire ancienne. Revue Française de 393 Géotechnique (134-135):65-74. (In French)

394

395 
Table 1: Classification of group UIC

\section{List of Figures}

Fig. 1: Cause of the problems for the deceleration of train

Fig. 2: Number of problems versus group UIC

Fig. 3: Problems occurring over one year. a) Problems related to the substructure and b) problems related to the sensitive zones

Fig. 4: Problems recorded versus type of track

Fig. 5: Classification of problems according to the territory. a) All problems; b) Problems related to substructure and c) sensitive zones

Fig. 6: Classification of problems according to the Infrapole. a) Problems related to sub-structure and b) problems related to sensitive zone

414 Fig. 8: Parameters used to calculate NL

415 Fig. 9: History of NL variations for a given kilometer, with maintenance operation

416 Fig. 10: Core sample from typical conventional railway sub-structure

417 Fig. 11: Typical result from Panda and Endoscope

418 Fig. 12: Degradation rate along the studied line

419 Fig. 13: Degradation rate of Track 1 according to (a) year of rail and (b) year of sleeper

420 Fig. 14: Degradation rate of Track 2 according to (a) year of rail and (b) year of sleeper

421 Fig. 15: Correlation between degradation rate of Track 1 and Track 2

422 Fig. 16: Correlation of the degradation rate to the thickness of interlayer and fouled ballast for Track 1-

423 Data from coring train. a) special zones and b) normal zone

424 Fig. 17: Correlation of the degradation rate to the thickness of interlayer and fouled ballast for Track 2-

425 Data from coring train. a) special zones and b) normal zone

426 Fig. 18: Correlation of the degradation rate to the thickness of interlayer and fouled ballast - Data from

427

428 
430 Table 1: Classification of group UIC

\begin{tabular}{|l|l|l|}
\hline Group UIC & Characteristic $T_{f 2}$ Value & Length (km) \\
\hline Group 1 & $T_{f 2}>120000$ & 0 \\
\hline Group 2 & $120000 \geq T_{f 2}>85000$ & 2385 \\
\hline Group 3 & $85000 \geq T_{f 2}>50000$ & 8968 \\
\hline $\begin{array}{l}\text { Group 4 } \\
\text { Group 5 }\end{array}$ & $50000 \geq T_{f 2}>28000$ & 12218 \\
\hline $\begin{array}{l}\text { Group 6 } \\
\text { Group 7 Passenger train and } \\
\text { Freight train }\end{array}$ & $7000 \geq T_{f 2}>3500$ & 6807 \\
\hline $\begin{array}{l}\text { Group } 8 \text { Passenger train and } \\
\text { Freight train }\end{array}$ & $3500 \geq T_{f 2}>1500$ & $\begin{array}{l}7381 \\
4149 \text { (Pass. Train) and 292 (Frei. } \\
\text { Train) }\end{array}$ \\
\hline $\begin{array}{l}\text { Group 9 Passenger train and } \\
\text { Freight train }\end{array}$ & $1500 \geq T_{f 2}$ & $\begin{array}{l}7607 \text { (Pass. Train) and } 1291 \text { (Frei. } \\
\text { Train) }\end{array}$ \\
\hline
\end{tabular}




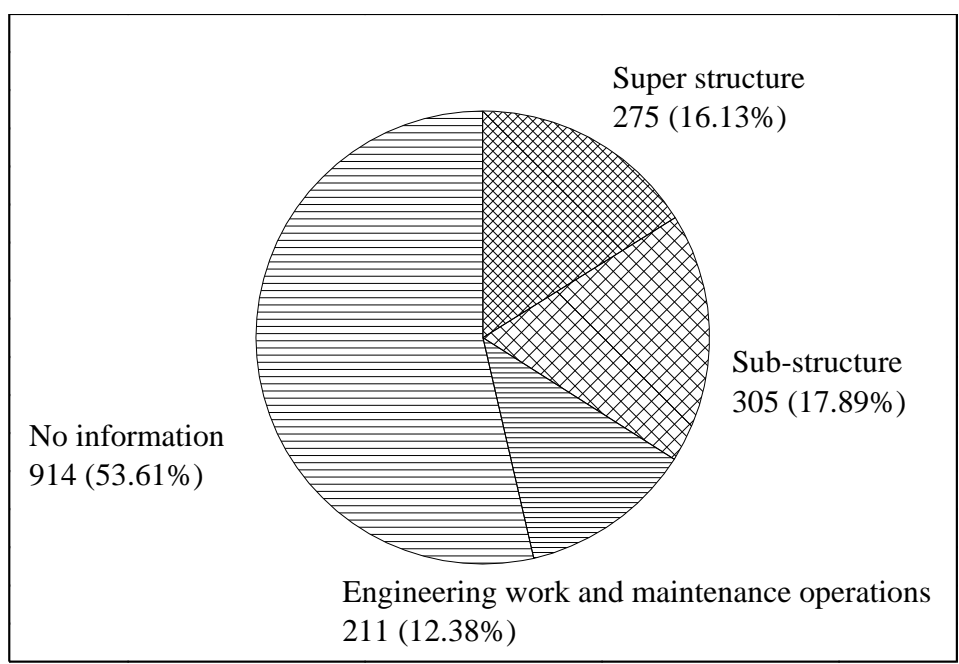

433

Fig. 1: Cause of the problems for the deceleration of train

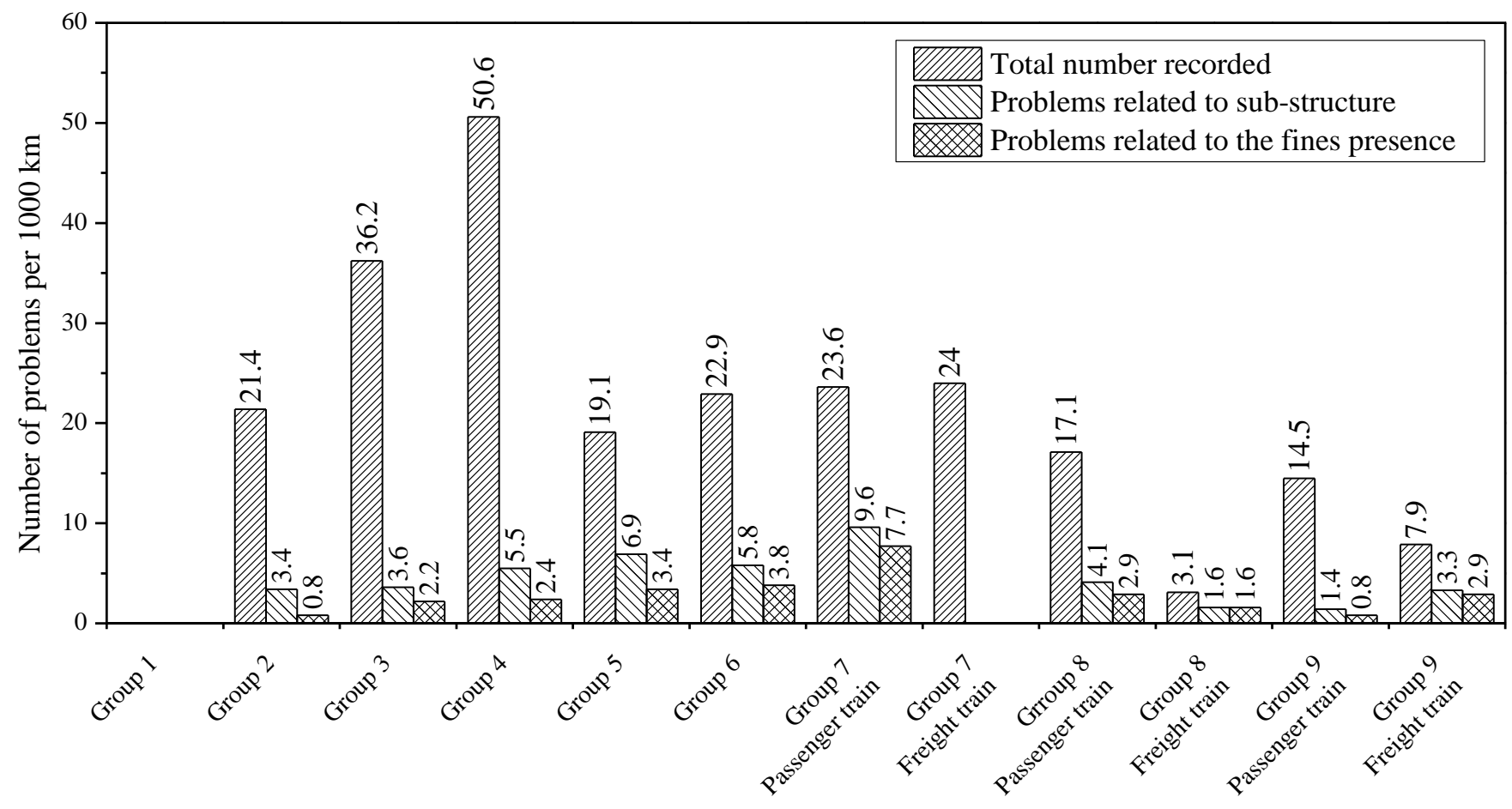

\section{Fig. 2: Number of problems versus group UIC}



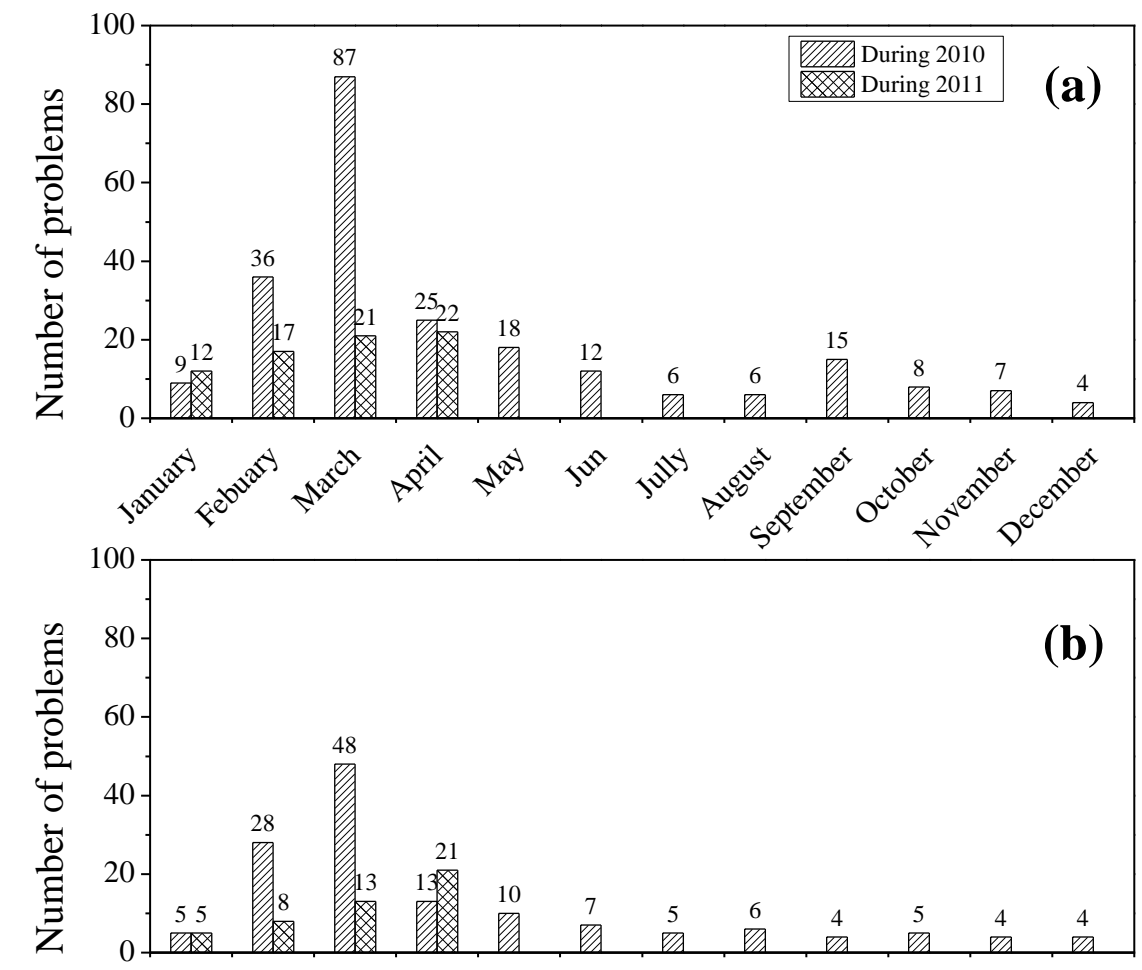

438 Fig. 3: Problems occurring over one year. a) Problems related to the substructure and b) problems related to the 439 sensitive zones

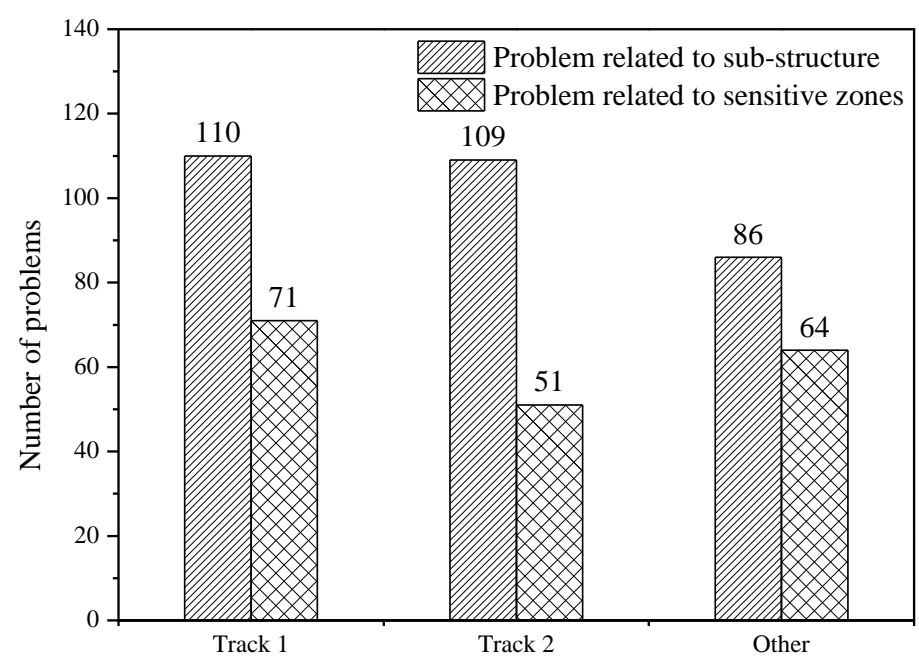

Fig. 4: Problems recorded versus type of track 

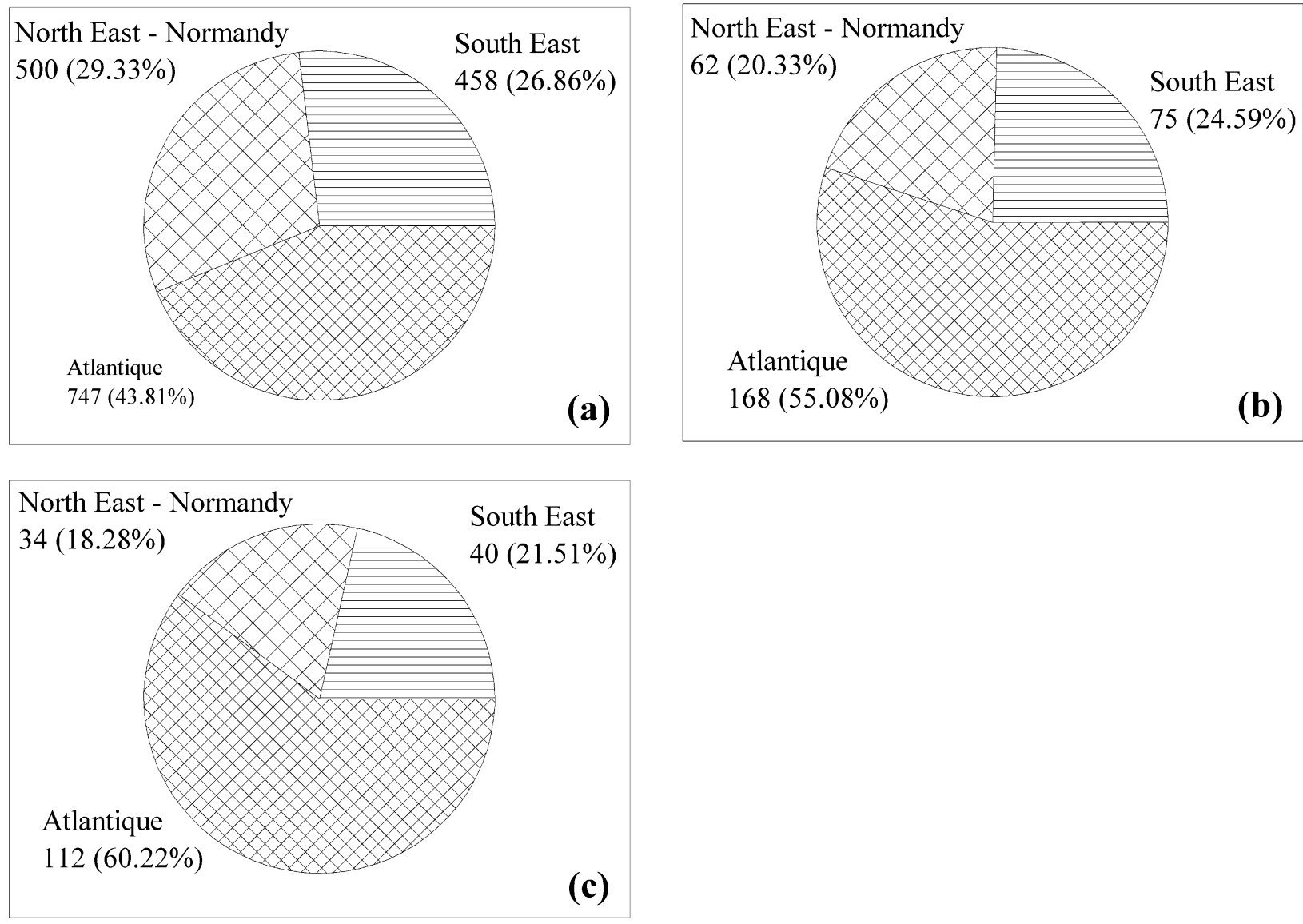

443 Fig. 5: Classification of problems according to the territory. a) All problems; b) Problems related to sub-structure and 444 c) sensitive zones 

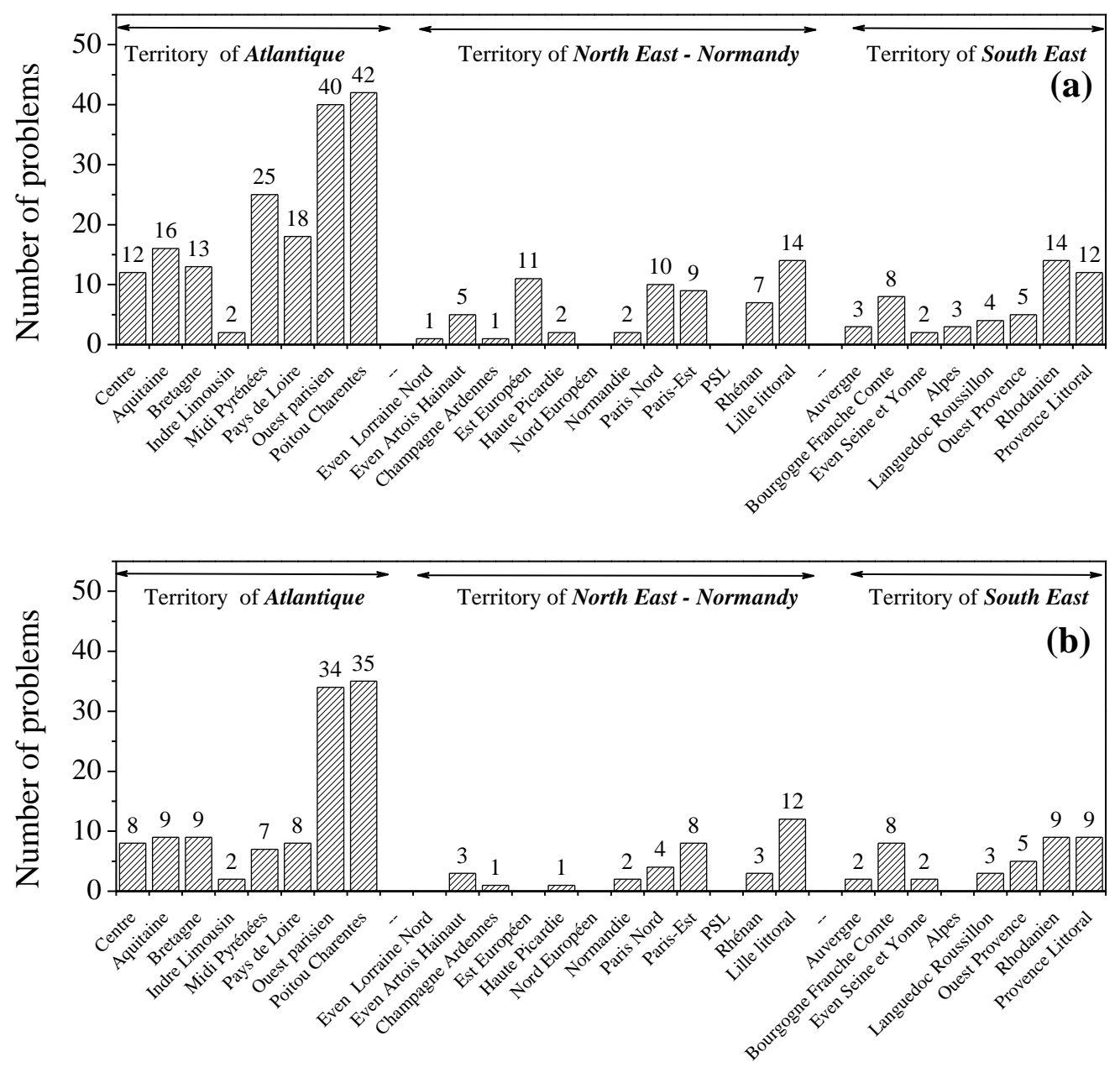

446

447 Fig. 6: Classification of problems according to the Infrapole. a) Problems related to sub-structure and b) problems 448 related to sensitive zone 


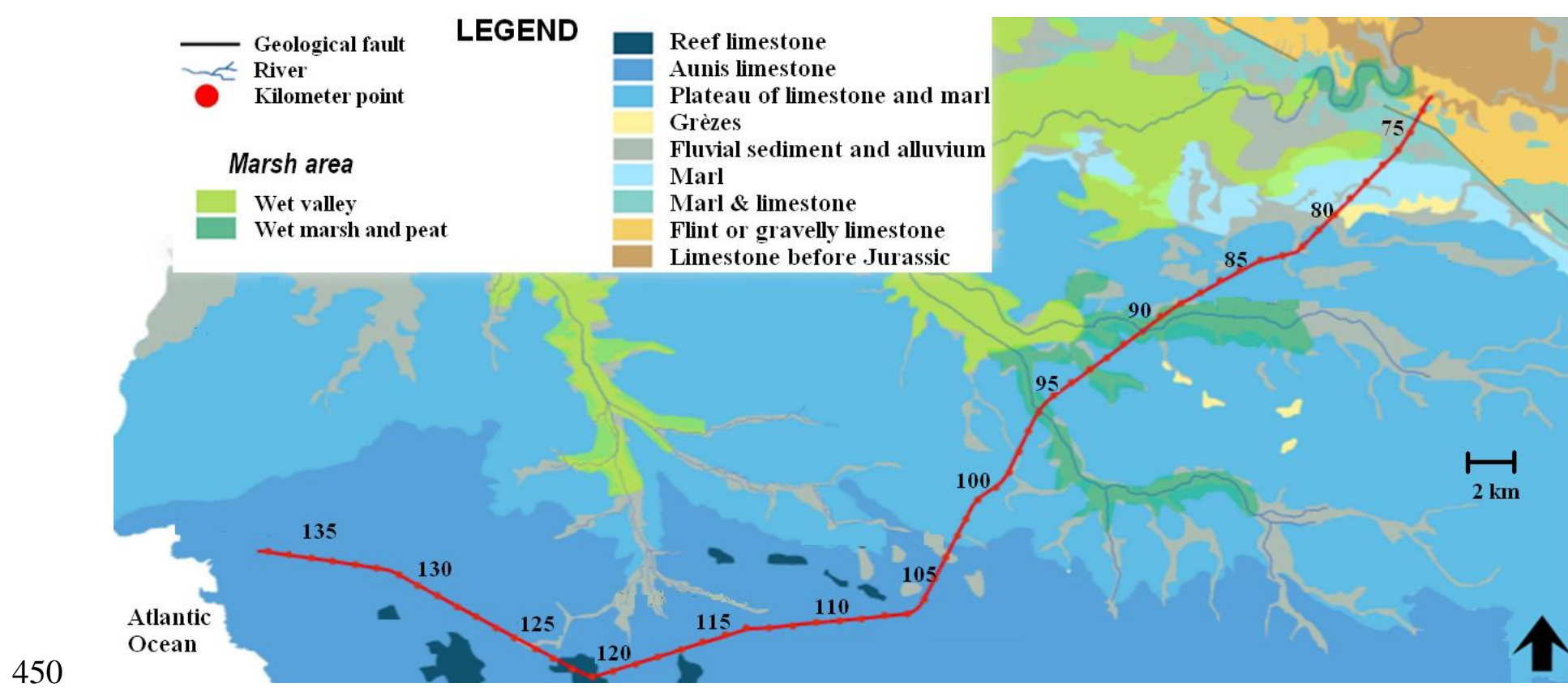

451 Fig. 7: Geological map of the studied line

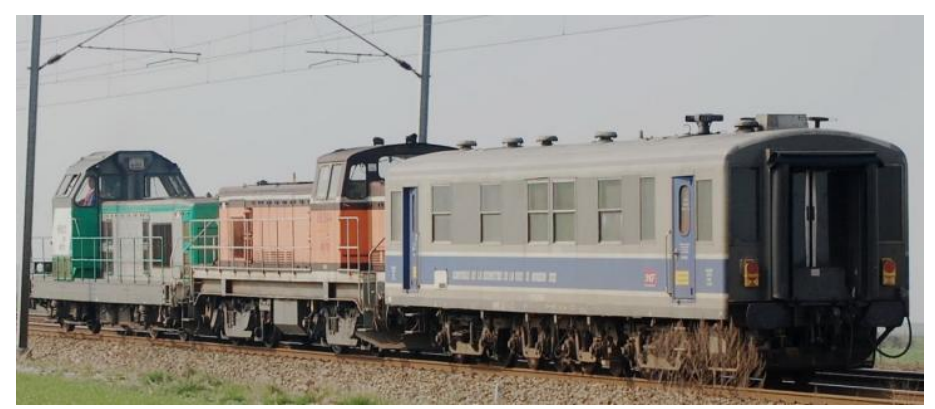

Fig 8a: Mauzin train

(http://lapassiondutrain.blogspot.f)

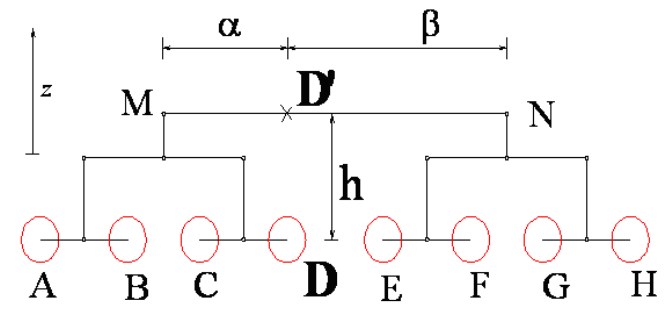

Fig. 8b: Parameters used to calculate NL 


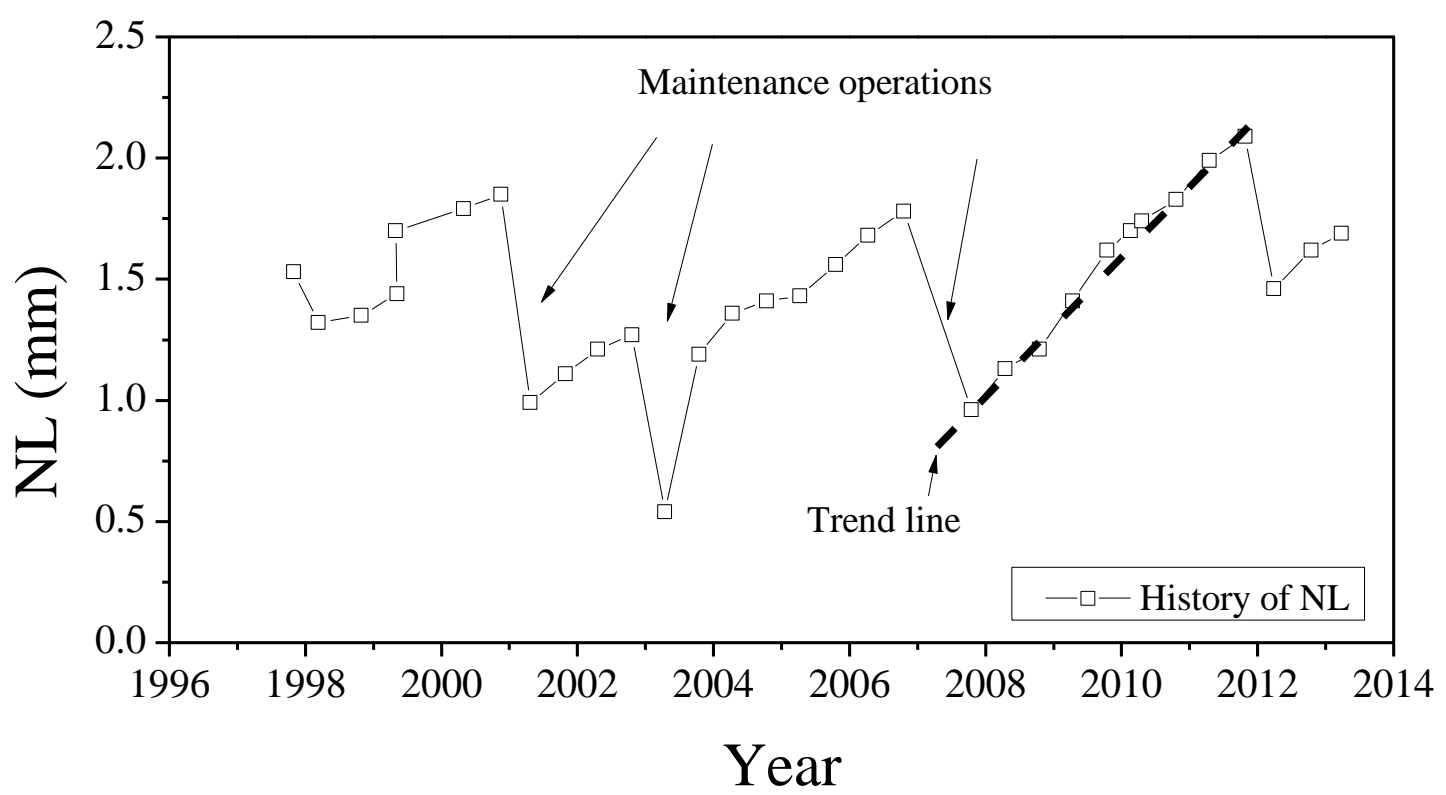

454

455 Fig. 9: History of $N L$ variations for a given kilometer, with maintenance operation

456 


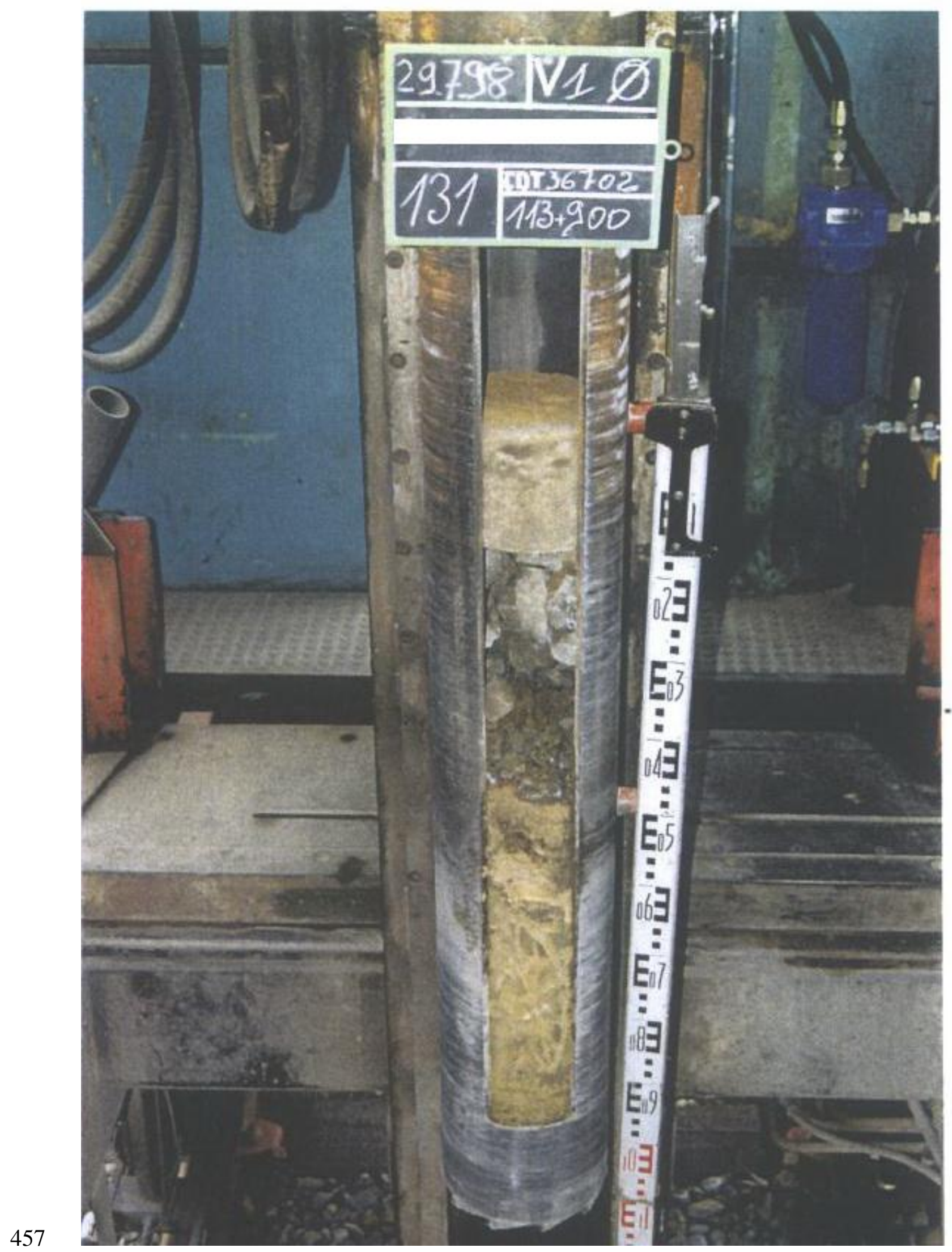

458 Fig. 10: Core sample from typical conventional railway sub-structure 
Cone resistance (MPa)

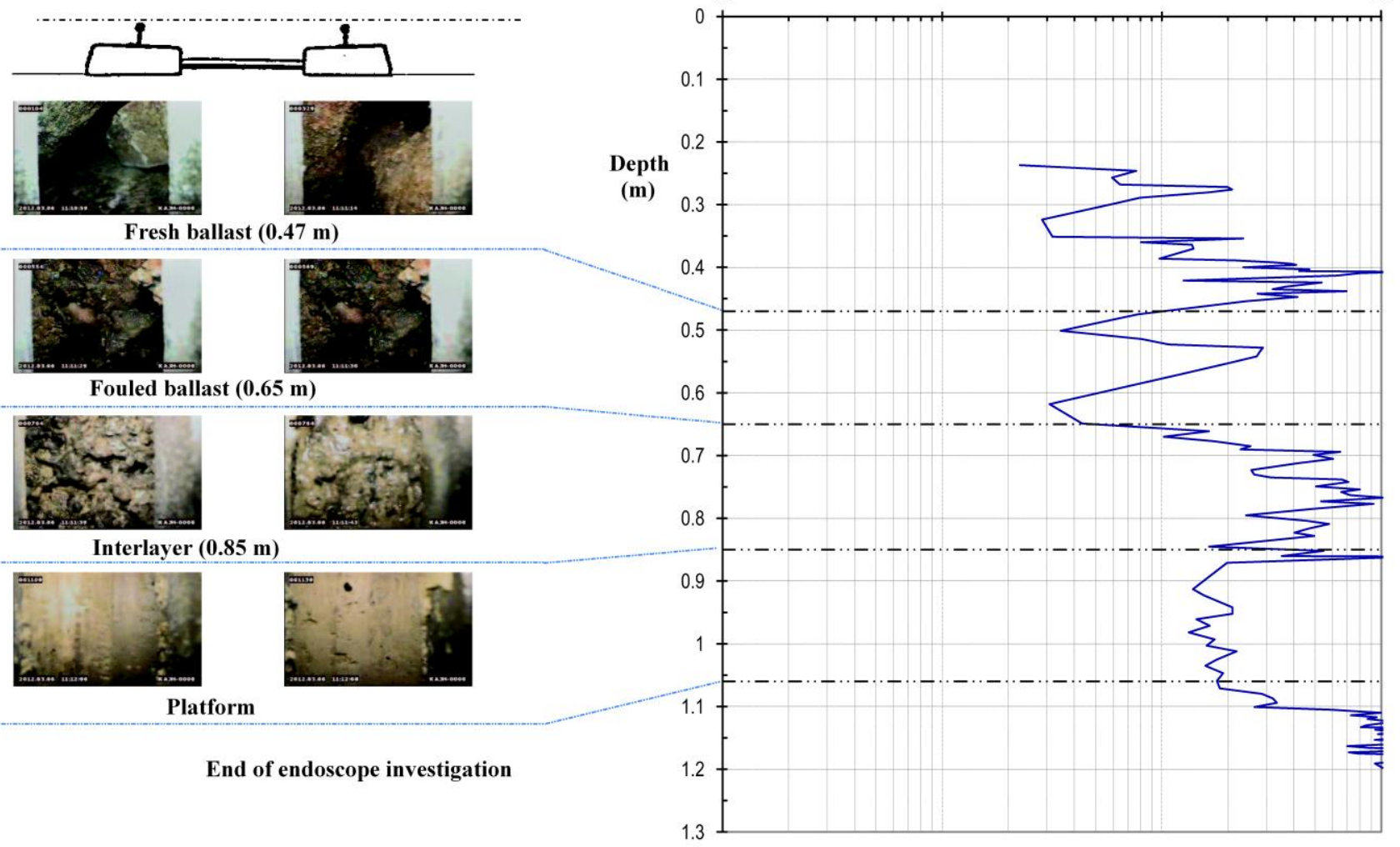

Fig. 11: Typical result from Panda and Endoscope

462

463

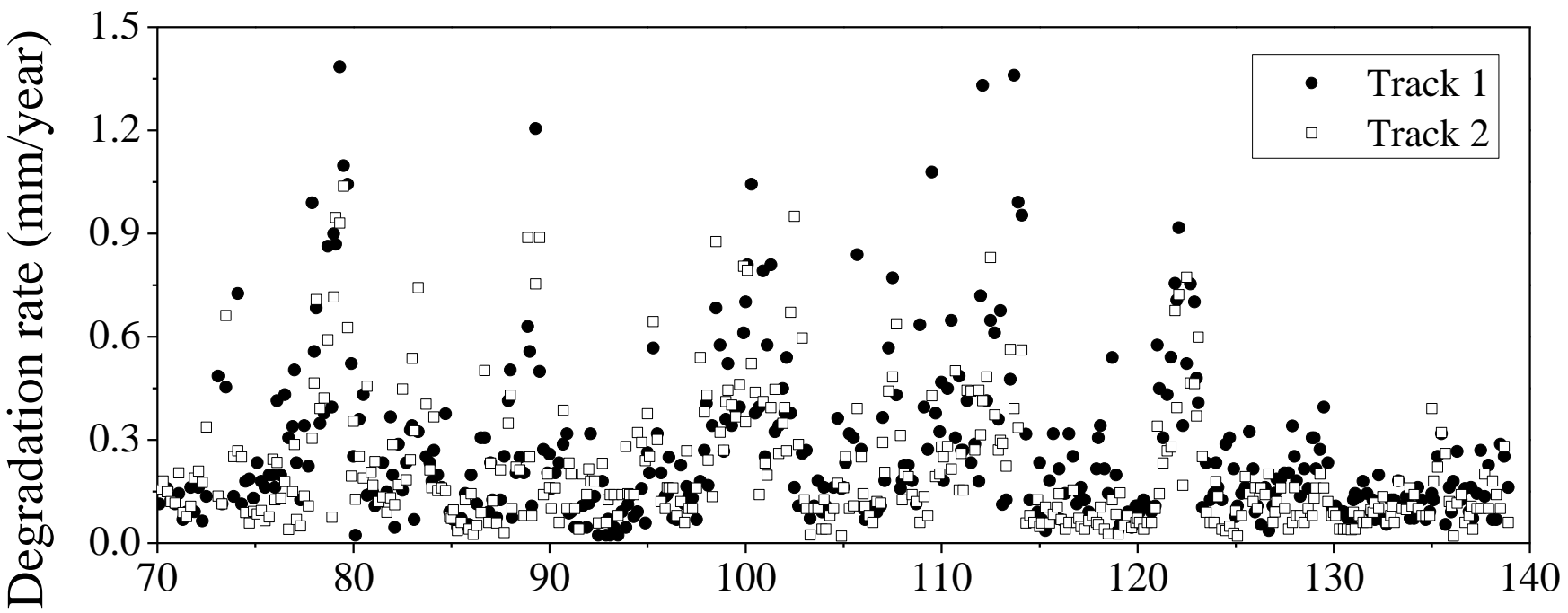

Fig. 12: Degradation rate along the studied line 


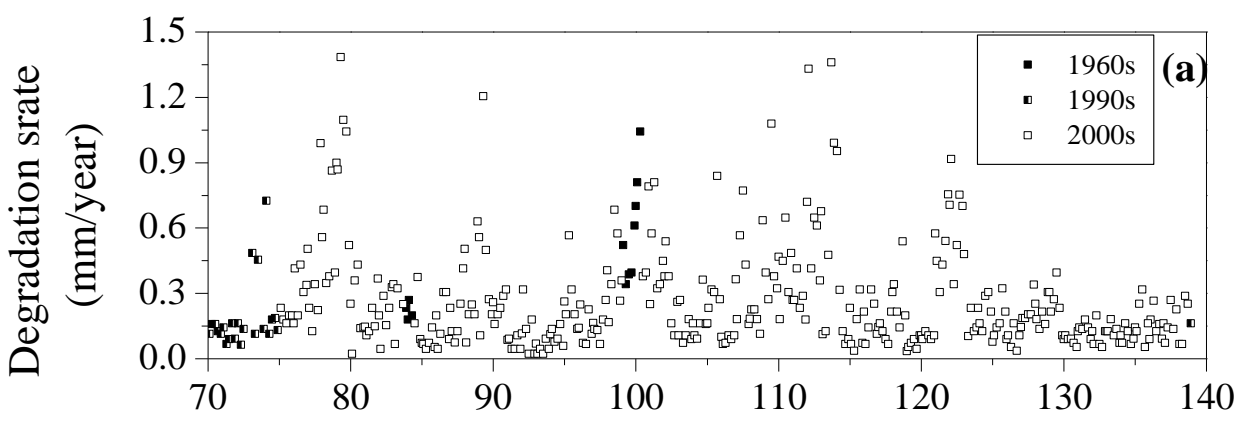

Kilometer

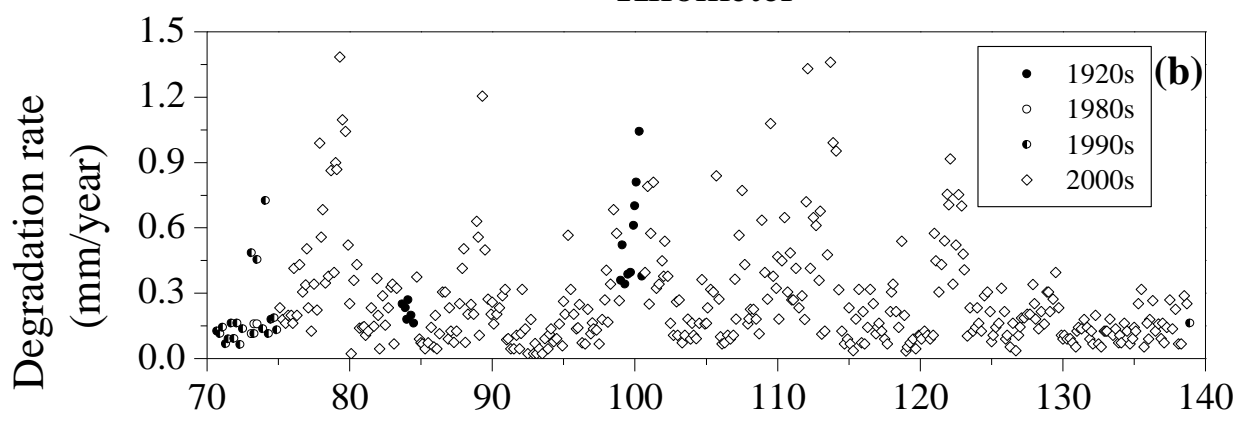

Kilometer

Fig. 13: Degradation rate of Track 1 according to (a) year of rail and (b) year of sleeper

470
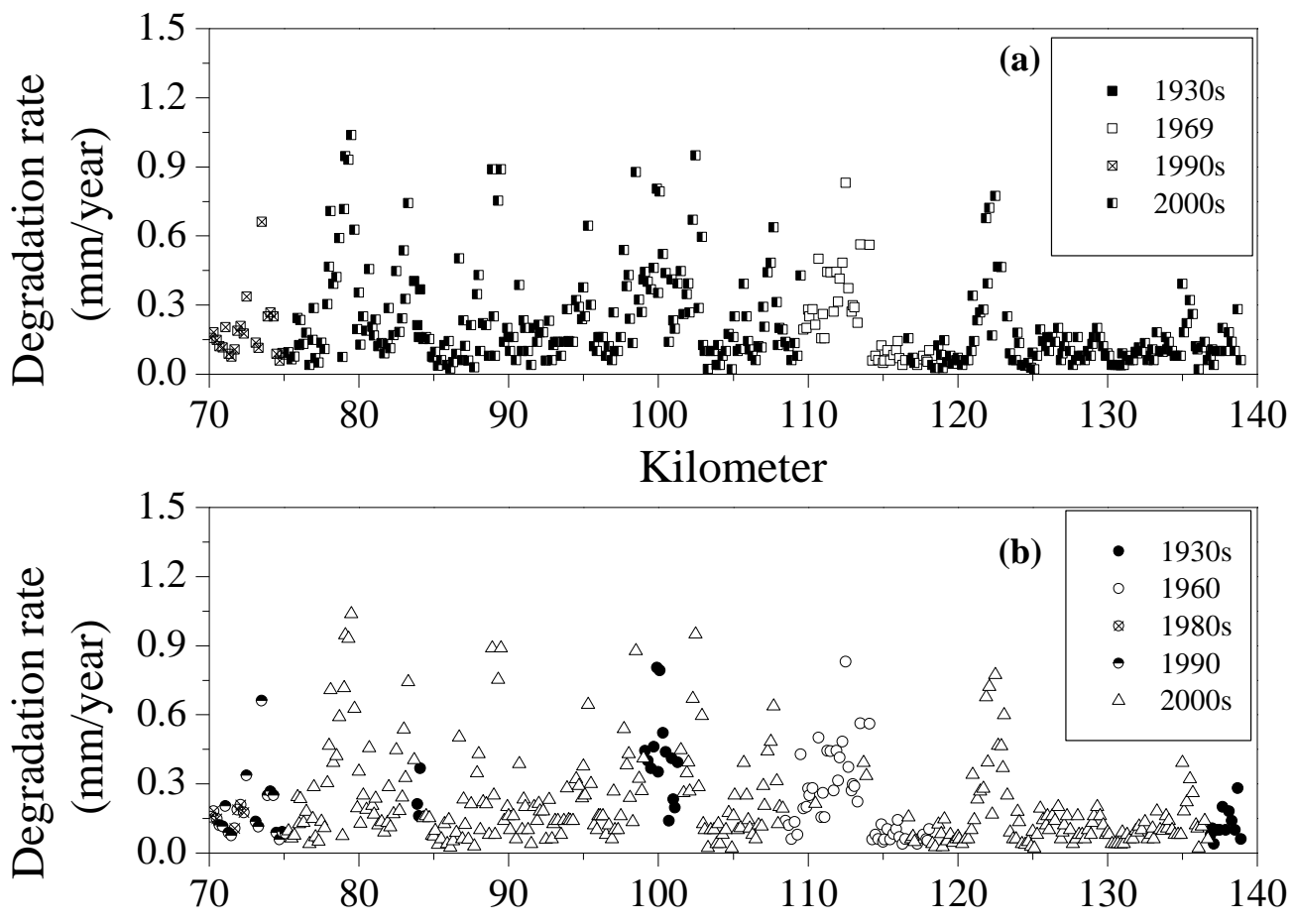

Kilometer

Fig. 14: Degradation rate of Track 2 according to (a) year of rail and (b) year of sleeper 


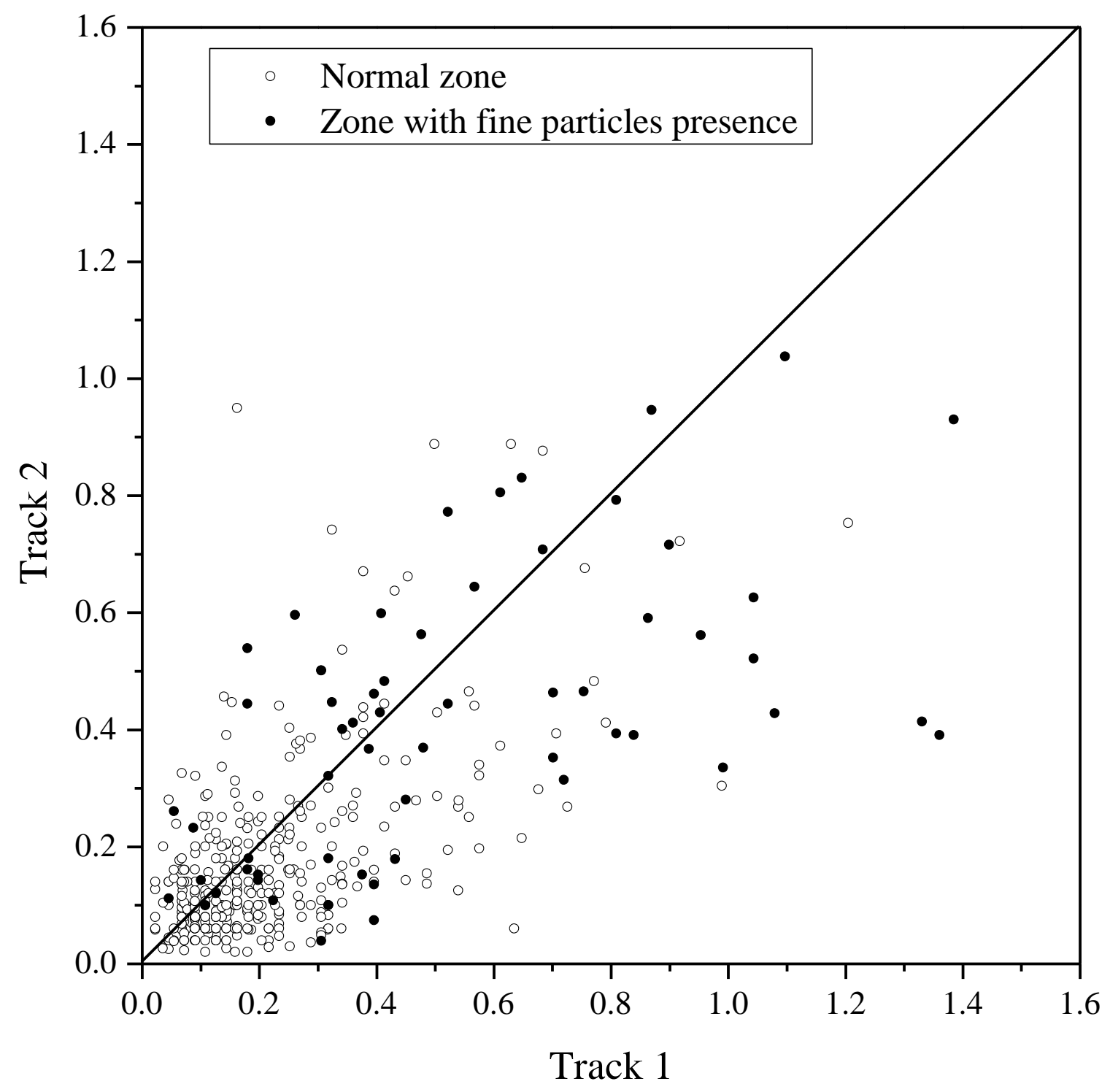

Fig. 15: Correlation between degradation rate of Track 1 and Track 2

477

478 

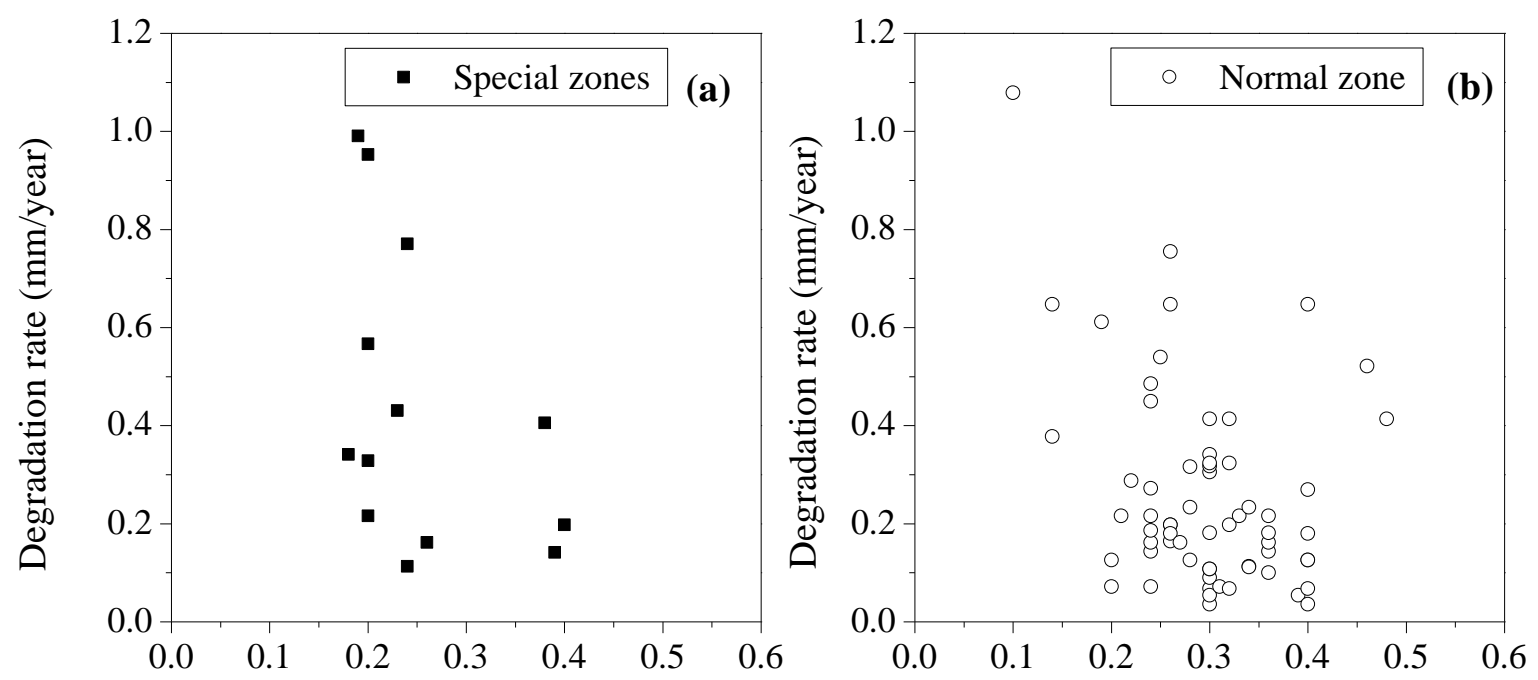

Fig. 16: Correlation of the degradation rate to the thickness of interlayer and fouled ballast for Track 1- Data from
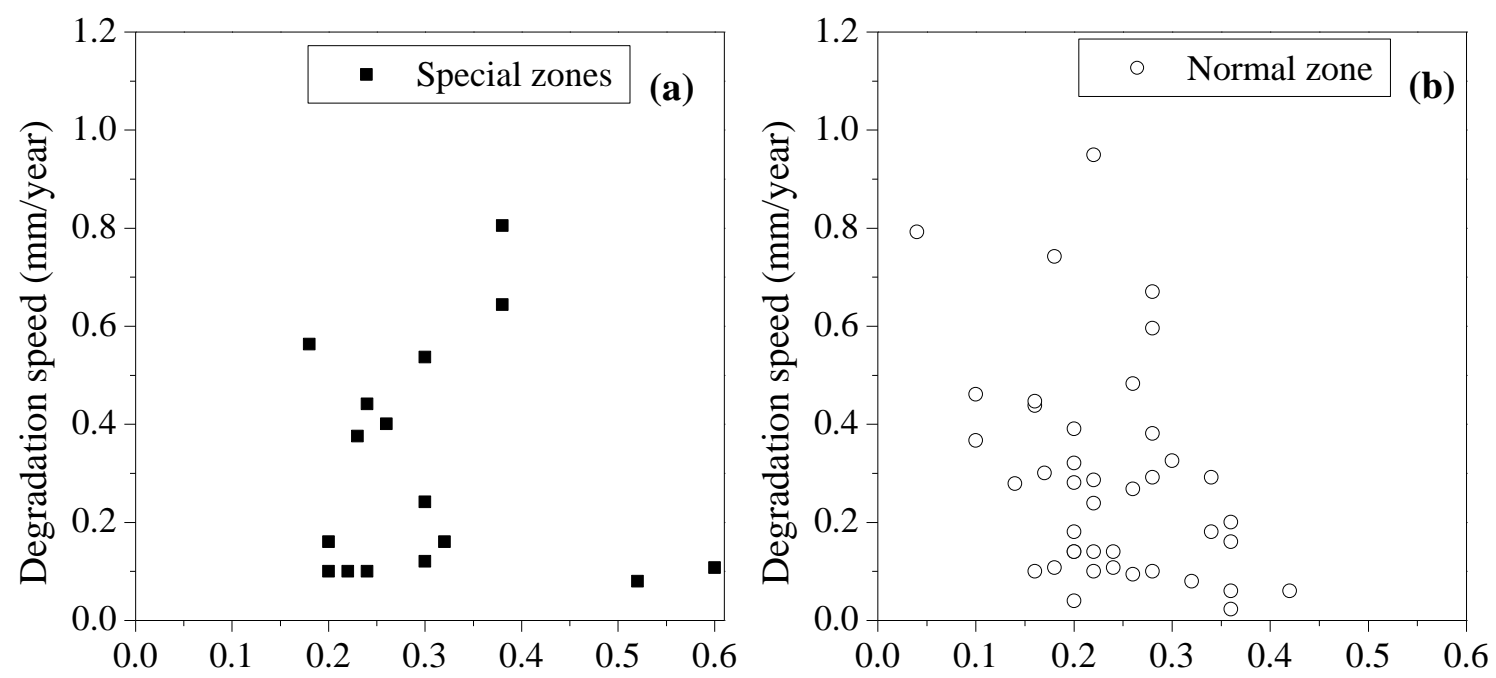

Thickness of interlayer and fouled ballast (m) Thickness of interlayer and fouled ballast (m)

Fig. 17: Correlation of the degradation rate to the thickness of interlayer and fouled ballast for Track 2- Data from 

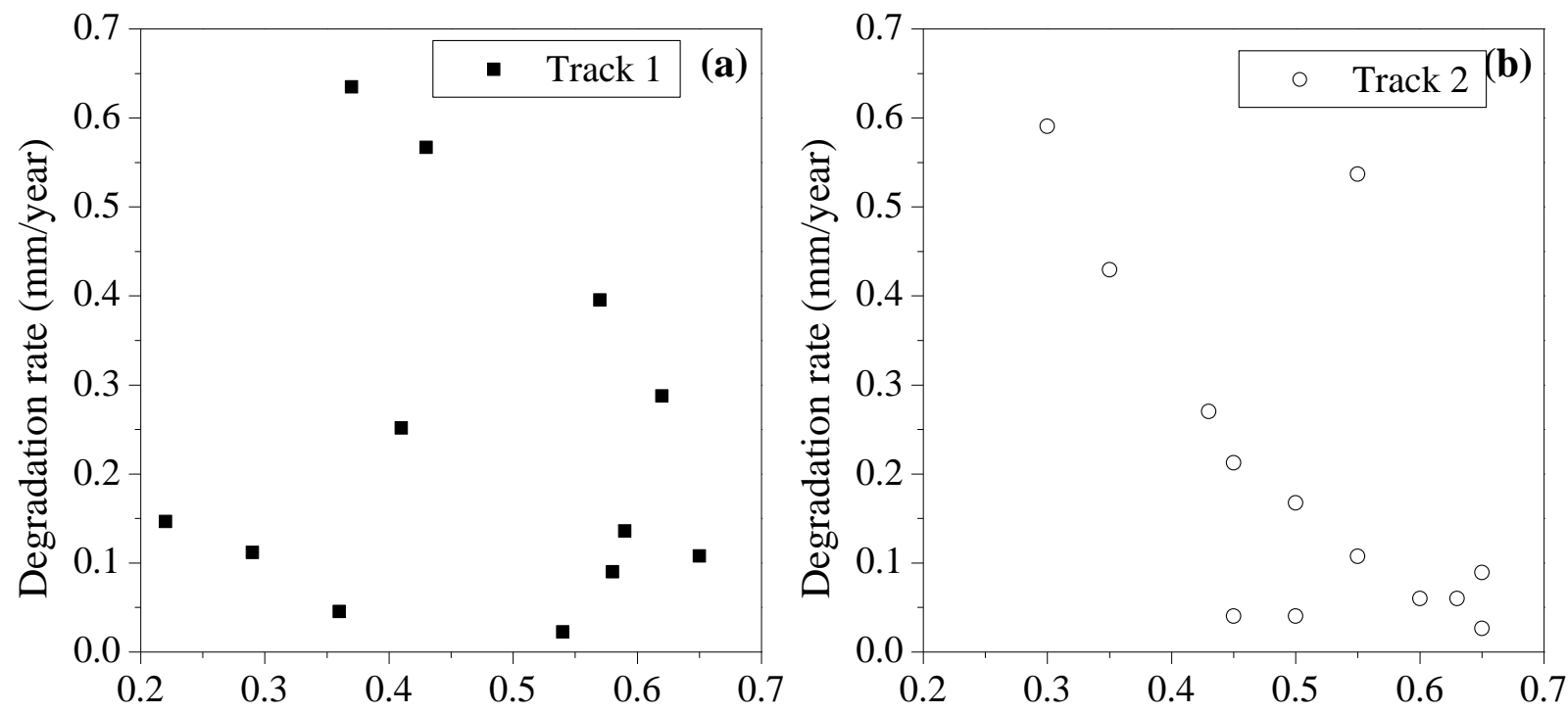

489

Thickness of interlayer and fouled ballast $(\mathrm{m})$

Thickness of interlayer and fouled ballast $(\mathrm{m})$

490

Fig. 18: Correlation of the degradation rate to the thickness of interlayer and fouled ballast - Data from Panda and

491 Endoscope. a) Track 1 and b) Track 2

492 